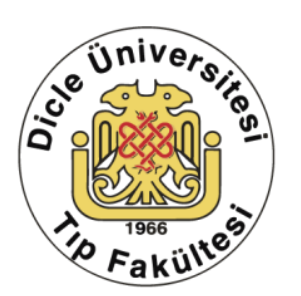

\title{
Factors Affecting Amputations in Patients with Diabetic Foot Ulcer Referring To the Emergency Units
}

\author{
Mustafa İçer, Hasan Mansur Durgun \\ Department of Emergency Medicine, Faculty of Medicine, Dicle University, Diyarbakır, Turkey
}

Received: 03.12.2016; Revised: 08.02.2017; Accepted: 09.02.2017

\begin{abstract}
Objective: Diabetic foot is the most common cause of lower extremity amputations. The aim of the present study was to investigate the clinical characteristics of and factors affecting amputation in patients with diabetic foot ulcer referring to the emergency units.

Methods: The present study was performed based on retrospective review of medical files of 58 patients who were referred to the Emergency Unit of Dicle University, Faculty of Medicine between June 2010 and October 2016 due to diabetic foot ulcer.

Results: Of 58 patients included in this study, 31 (53.4\%) were men and 27 (46.6\%) were women. The mean age was $61.43 \pm 11.584$ (range: 41 to 85 ) years. Extremity amputation was not performed in 34 patients (58.6\%), while 24 $(41.4 \%)$ underwent an amputation. Factors affecting extremity amputation were found to be disease duration, presence of coronary artery disease, duration of hospital stay, and presence of osteomyelitis. Among laboratory findings, factors affecting extremity amputation were albumin, hemoglobin, leukocytes, neutrophil, neutrophil/lymphocyte ratio, hemoglobin A1c, and elevated erythrocyte sedimentation rate. The Wagner-Meggitt Classification of Grade 4, University of Texas Classification of stage D and Grade 3 also had significant effects on amputation. $(\mathrm{p}<0.05)$

Conclusion: Our study results suggest that together with classification systems, comorbidities, albumin levels, hemoglobin A1c levels, sedimentation rate, and complete blood count results play a key role in predicting the amputation requirement in patients with diabetic foot ulcers referring to the emergency units.
\end{abstract}

Keywords: Diabetic foot ulcer, diabetic foot amputation, emergency unit.

DOI: 10.5798/dicletip.298615

Yazışma Adresi / Correspondence: Mustafa İcer, Department of Emergency Medicine, Faculty of Medicine, Dicle University, 21280, Diyarbakır, Turkey Email:drmicer@gmail.com 


\section{Acil Servise Başvuran Diyabetik Ayak Hastalarında Amputasyonu Etkileyen Faktörler}

\section{Özet}

Giriş: Diyabetik ayak nontravmatik alt ekstremite ampütasyonlarının en yaygın nedenidir. Bu çalışmanın amacı acil servise başvuran diyabetik ayak hastalarının klinik öz elliklerini ve ampütasyonu etkileyen faktörleri incelemektir.

Yöntemler: Bu çalışma Haziran 2010-Ekim2016 tarihleri arasında Dicle Üniversitesi Tıp Fakültesi Acil Servisi'ne diyabetik ayak ülseri nedeni ile başvuran 58 hasta retrospektif olarak hasta dosyaları incelenerek yapıldı.

Bulgular: $\mathrm{Bu}$ çalışmada toplamda 58 olgunun31(\%53,4)'i erkek, 27(\%46,6)'i kadındı. Yaş ortalaması

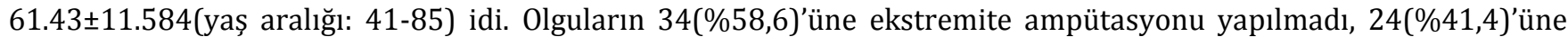
yapıldı. Hastalık süresi, koroner arter hastalığı, hastaneye yatış süresi, osteomiyelit varlığı ekstremite ampütasyonunu etkileyen faktörlerdi. Laboratuvar bulgularından albümin, hemoglobin, lökosit, nötrofil, nötrofil/lenfosit oranı hemoglobin A1c, eritrosit sedimetasyon hızı yüksekliği ekstremite ampütasyonunu etkileyen faktörlerdi. WagnerMeggitt sinıflamasında derece 4, University of Texas sınıflamasında evre D ve derece 3 ampütasyonu etkileyen faktörlerdi $(\mathrm{p}<0.05)$.

Sonuç: Acil servise başvuran diyabetik ayak ülserli hastalarda sınıflama sistemleri ile beraber, eşlik eden komorbid durumlar, albümin, hemoglobin A1c, eritrosit sedimetasyon hızı ve tam kan sayımı ampütasyonu belirlemede önemlidir.

Anahtar kelimeler: Diyabetik ayak ülseri, diyabetik ayak ampütasyonu, acil servis.

\section{INTRODUCTION}

Diabetes mellitus (DM) is the leading cause of chronic disorders and extremity loss worldwide. It currently affects about 382 million individuals and by the year 2035, this figure is estimated to reach 592 million [1]. Almost $15 \%$ of diabetic patients develop foot ulcer (DFU) at any time point in their lives and 14 to $24 \%$ of DFU ultimately result in lower extremity amputations [2]. In developed countries, diabetic foot is the most common cause of non-traumatic lower extremity amputations [3]. The main risk factors for diabetic patients to develop foot ulcers include the loss of ability for protection due to neuropathy, previous ulcers and amputations, overpressure, external trauma, infections, and ischemia due to peripheral artery disease [4].

In the present study, we investigated clinical characteristics of and factors affecting amputation in patients with DFU referring to the emergency units.

\section{METHODS}

The present study was performed based on retrospective review of medical files of 58 patients who were referred to the Emergency Unit of Dicle University, Faculty of Medicine, between June 2010 and October 2016 due to DFU. On admission, the patients' initial care was provided in the emergency unit. Based on indications, the patients were externalized or admitted to infectious diseases, endocrinology, plastic surgery or orthopaedics clinics for further treatment. Patients with missing data and those with non-DM related foot ulcers or gangrene were excluded. The analyses were based on laboratory data recorded at the patients' initial admission to the emergency unit.

Data analyzed in the study included age, sex, disease duration, comorbidities such as coronary artery disease, hypertension, chronic obstructive pulmonary disease, cerebrovascular disease, chronic kidney failure and peripheral artery disease, osteomyelitis, extremity amputation, antidiabetic treatments, 
duration of hospital stay, and laboratory findings including albumin, glucose, hemoglobin (hb), hematocrit (htc), white blood cells (WBC), neutrophiles, lymphocytes, neutrophil/lymphocyte ratio, hemoglobin HbA1c (HbA1c), c-reactive protein (CRP), and erythrocyte sedimentation rate (ESR). Localization of the foot ulcer was also recorded (Figure 1) [5], and was evaluated according to the Wagner-Meggitt Classification and University of Texas Classification (Tables 1 and 2) [6]. The patients were divided into two groups as amputated and non-amputated. Factors affecting extremity amputation were reviewed based on these data.

Table 1: Wagner-Meggitt Classification of Diabetic Foot[6].

\section{Grades Lesions}

Grade0 No ulser

Grade1 Superficial ulcers

Grade2 Deep ulcers

Grade3 Ulcer with bone involvement

Grade4 Forefoot gangrene

Grade5 Whole foot gangrene

\begin{tabular}{llll}
\multicolumn{2}{l}{ Table 2: University of Texas Classification of Diabetic Foot [6]. } \\
\hline StageA & No infection or ischemia & Grade0 & Epithelialized wound \\
StageB & Infection available & Grade1 & $\begin{array}{l}\text { Superficial wound } \\
\text { StageC }\end{array}$ \\
Ischemia available & Grade2 $\begin{array}{l}\text { Wound penetrates to } \\
\text { tendon or capsule }\end{array}$ \\
StageD & $\begin{array}{l}\text { Infection and ischemia } \\
\text { available }\end{array}$ & Grade3 & $\begin{array}{l}\text { Wound penetrates to } \\
\text { bone or joint }\end{array}$ \\
\hline
\end{tabular}

\section{Statistical Analysis}

Statistical analysis was performed using the SPSS version 18.0 for Windows software (SPSS Inc., Chicago, IL, USA). Numeric variables were presented in mean \pm standard deviation (SD), while categoric variables were expressed in number and percentage (\%). Normally distributed data were compared between two groups using the independent t-test. Abnormally distributed data were compared between two groups using the Mann-Whitney U Test. The chi-square $(\chi 2)$ test was used to compare the qualitative data between the groups. All hypothesis were two-sided and a $\mathrm{p}$ value of $\leq 0.05$ was considered statistically significant.

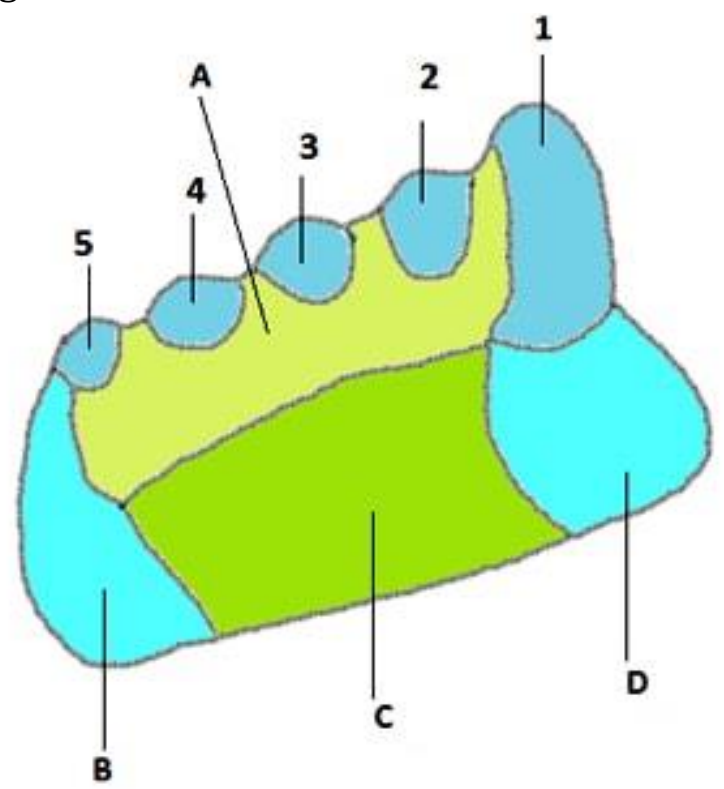

Figure 1: Transversal section of the foot. Spaces: Numbers 1-5 indicate metatarsals; A, deep interosseous; B, lateral plantar; C, central plantar; D, medial plantar [5].

\section{RESULTS}

Of 58 patients, 31 (53.4\%) were men and 27 $(46.6 \%)$ were women. The mean age was $61.43 \pm 11.584$ (range: 41 to 85 ) years. Of all, 35 patients $(60.3 \%)$ were younger than 65 years. The mean disease duration was $11.83 \pm 5.78$ year. In total, 26 patients (44.8\%) had comorbidities. Comorbidities accompanying diabetic foot, in order of frequency, were as follows: coronary artery disease in 11 patients (19\%), hypertension in 18 (31\%), chronic obstructive pulmonary disease in one $(1.7 \%)$, cerebrovascular disease in two (3.4\%), chronic renal failure in seven (12.1\%), and peripheral artery disease in three patients (5.2\%). The mean laboratory results were as follows: albumin $2.75 \pm 0.79$, glucose $235.09 \pm 107.59, \mathrm{Hb}$

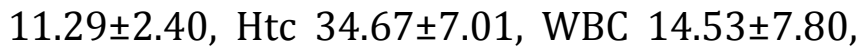
neutrophils $11.28 \pm 7.66$, lymphocytes $2.14 \pm 0.95$, neutrophil/lymphocyte ratio

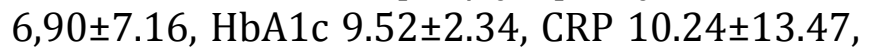
and ESR 40.74 \pm 17.15 . The mean duration of hospital stay was $11.52 \pm 9.42$ days. Of all 
patients, 28 (48.3\%) had osteomyelitis (Table 3).

Extremity amputation was not performed in 34 patients (58.6\%), while 24 (41.4\%) underwent an amputation. Factors significantly affecting extremity amputation were as follows: disease duration, presence of coronary artery disease, duration of hospital stay, and presence of osteomyelitis $(\mathrm{p}<0.05)$. Among laboratory findings, albumin, $\mathrm{Hb}, \mathrm{WBC}$, netrophils, neutrophil/lymphocyte ratio, $\mathrm{HbA1c}$, and elevated ESR had a significant impact on extremity amputation $(\mathrm{p}<0.05)$ (Table 4).

\begin{tabular}{|c|c|c|c|c|}
\hline Characters & Total n(\%) & Amputated n(\%) & Non-amputated n(\%) & $P$ value \\
\hline $\mathrm{Age}^{\mathrm{a}}$ & $61.43 \pm 11.584$ & $62,17 \pm 13.18$ & $60.91 \pm 10.49$ & 0.688 \\
\hline$<65$ age & $35(60,3)$ & $13(54.2)$ & $22(64.7)$ & 0.419 \\
\hline$\geq 65$ age & $23(39.7)$ & $11(45.8)$ & $12(35.3)$ & \\
\hline \multicolumn{5}{|l|}{ Gender } \\
\hline Male & $31(53.4)$ & $16(66,7)$ & $15(44.1)$ & 0.090 \\
\hline Female & $27(46.6)$ & $8(33.3)$ & $19(55.9)$ & \\
\hline DM duration $^{a}$ & $11,83 \pm 5.78$ & $9.92 \pm 6.10$ & $13.18 \pm 5.21$ & 0.033 \\
\hline$<5$ year & $9(15.5)$ & $8(33.3)$ & $1(2.9)$ & 0.002 \\
\hline 6-10 year & $20(34.5)$ & $6(25)$ & $14(41.2)$ & 0.202 \\
\hline 11-19 year & $24(41.4)$ & $9(37.5)$ & $15(44.1)$ & 0.614 \\
\hline$>20$ year & $5(8.6)$ & $1(4.2)$ & $4(11.8)$ & 0.310 \\
\hline Comorbidity & $26(44.8)$ & $11(45.8)$ & $15(44.1)$ & 0.897 \\
\hline $\mathrm{CAD}$ & $11(19)$ & $8(33.3)$ & $3(8.8)$ & 0.019 \\
\hline Hypertension & $18(31)$ & $6(25)$ & $12(35.3)$ & 0.404 \\
\hline COPD & $1(1.7)$ & $0(0)$ & $1(2.9)$ & 0.397 \\
\hline SVD & $2(3.4)$ & $0(0)$ & $2(5.9)$ & 0.227 \\
\hline CKF & $7(12.1)$ & $2(8.3)$ & $5(14.7)$ & 0.463 \\
\hline PAD & $3(5.2)$ & $1(4.2)$ & $2(5.9)$ & 0.771 \\
\hline \multicolumn{5}{|l|}{ Laboratory findings } \\
\hline Albumin $^{a}$ & $2.75 \pm 0.79$ & $2.30 \pm 0.65$ & $3.07 \pm 0.72$ & $<0.001$ \\
\hline Glucose $^{a}$ & $235.09 \pm 107.59$ & $257.38 \pm 126.61$ & $219.35 \pm 90.60$ & 0.187 \\
\hline Hemoglobin $^{a}$ & $11.29 \pm 2.40$ & $10.59 \pm 2.66$ & $11.79 \pm 2.10$ & 0.062 \\
\hline Hematocrit $^{a}$ & $34.67 \pm 7.01$ & $32.43 \pm 7.91$ & $36.26 \pm 5.91$ & 0.24 \\
\hline $\mathrm{WBC}^{a}$ & $14.53 \pm 7.80$ & $19.34 \pm 9.20$ & $11.13 \pm 4.17$ & $<0.001$ \\
\hline Neutrophiles $^{a}$ & $11.28 \pm 7.66$ & $16.06 \pm 9.19$ & $7.91 \pm 3.78$ & $<0.001$ \\
\hline Lymphocytes $^{a}$ & $2.14 \pm 0.95$ & $2.11 \pm 0.99$ & $2.17 \pm 0.93$ & 0.835 \\
\hline $\mathrm{N} / \mathrm{L}$ ratio ${ }^{a}$ & $6,90 \pm 7.16$ & $10.34 \pm 9.36$ & $4.48 \pm 3.60$ & 0.002 \\
\hline $\mathrm{HbA1c^{a }}$ & $9.52 \pm 2.34$ & $10.37 \pm 2.51$ & $8.91 \pm 2.03$ & 0.018 \\
\hline $\mathrm{CRP}^{a}$ & $10.24 \pm 13.47$ & $13.40 \pm 8.63$ & $8.01 \pm 15.79$ & 0.135 \\
\hline $\operatorname{ESR}^{a}$ & $40.74 \pm 17.15$ & $48.83 \pm 12.01$ & $35.03 \pm 18.07$ & 0.002 \\
\hline Duration of hospital stay (day) ${ }^{a}$ & $11.52 \pm 9.42$ & $14.79 \pm 8.85$ & $9.21 \pm 9.25$ & 0.025 \\
\hline osteomyelitis & $28(48.3)$ & $21(87.5)$ & $7(20.6)$ & $<0.001$ \\
\hline \multicolumn{5}{|l|}{ Antidiabetic treatments } \\
\hline $\mathrm{OAD}$ & $14(24.1)$ & $5(20.8)$ & $9(26.5)$ & 0.621 \\
\hline Insulin & $27(46.6)$ & $10(41.7)$ & $17(50)$ & 0.531 \\
\hline
\end{tabular}

DM: Diabetes mellitus, CAD: coronary artery disease, hypertension, COPD: chronic obstructive pulmonary disease, SVD: cerebrovascular disease, CKF: chronic kidney failure, PAH: peripheral artery disease, WBC: white blood cells, N/L ratio: neutrophil/lymphocyte ratio, HbA1c: hemoglobin HbA1c, CRP: c-reactive protein, ESR: erythrocyte sedimentation rate, OAD: oral antidiabetic, ${ }^{\text {a }}$ : Mean \pm SD.
Based on the Wagner-Meggitt Classification, the majority of the patients had Grade 2 (27 [46.6\%]) and Grade 4 disease (17 [29.3\%]). Grade 2 disease was associated with nonamputation $(\mathrm{p}<0.001)$. However, Grade 4 disease was a factor affecting extremity amputation $(\mathrm{p}<0.01)$. According to the University of Texas Classification, the majority of the patients had Stage B $(n=28,48.3 \%)$ and Stage D disease $(n=26,44.8 \%)$, and Grade 1 $(n=20,34.5 \%)$ and Grade 3 disease $(n=27$, 46.6\%). Stage B and Grade 1 were associated with non-amputation $(\mathrm{p}<0.001)$. However, Stage D and Grade 3 were the main factors affecting extremity amputation $(\mathrm{p}<0.01)$. In terms of ulcer localization, the majority of the patients had ulcers located on the 1-5th metatarsals, which was also a factor affecting extremity amputation $(\mathrm{p}<0.01)$ (Table 4).

\begin{tabular}{|c|c|c|c|c|}
\hline Characters & Total n(\%) & Amputated n(\%) & Non-amputated n(\%) & $P$ value \\
\hline \multicolumn{5}{|l|}{ Wagner-Meggitt } \\
\hline Grade1 & $2(3.4)$ & $0(0)$ & $2(5.9)$ & 0.227 \\
\hline Grade2 & $27(46.6)$ & $1(4.2)$ & $26(76.5)$ & $<0.001$ \\
\hline Grade3 & $10(17.2)$ & $4(16.7)$ & $6(17.6)$ & 0.922 \\
\hline Grade4 & $17(29.3)$ & $17(70.8)$ & $0(0)$ & $<0.001$ \\
\hline Grade5 & $2(3.4)$ & $2(8.3)$ & $0(0)$ & 0.087 \\
\hline \multicolumn{5}{|l|}{ University of Texas } \\
\hline StageA & $1(1.7)$ & $0(0)$ & $1(2.9)$ & 0.397 \\
\hline StageB & $28(48.3)$ & $1(4.2)$ & $27(79.4)$ & $<0.001$ \\
\hline StageC & $3(5.2)$ & $1(4.2)$ & $2(5.9)$ & 0.771 \\
\hline StageD & $26(44.8)$ & $22(91.7)$ & $4(11.8)$ & $<0.001$ \\
\hline Grade0 & $1(1.7)$ & $0(0)$ & $1(2.9)$ & 0.397 \\
\hline Grade1 & $20(34.5)$ & $0(0)$ & $20(58.8)$ & $<0.001$ \\
\hline Grade2 & $10(17.2)$ & $0(0)$ & $10(29.4)$ & 0.003 \\
\hline $\begin{array}{l}\text { Grade3 } \\
\text { Wound localization }\end{array}$ & $27(46.6)$ & $24(100)$ & $3(8.8)$ & $<0.001$ \\
\hline 1-5 metatarsals & $40(69)$ & $21(87.5)$ & $19(55.9)$ & 0.01 \\
\hline central plantar space & $10(17.2)$ & $5(20.8)$ & $5(14.7)$ & 0.543 \\
\hline dorsal plantar space & $13(22.4)$ & $5(20.8)$ & $8(23.5)$ & 0.808 \\
\hline lateral plantar space & $7(12.1)$ & $5(20.8)$ & $2(5.9)$ & 0.085 \\
\hline medial planter space & $6(10.3)$ & $4(16.7)$ & $2(5.9)$ & 0.184 \\
\hline
\end{tabular}




\section{DISCUSSION}

Diabetic foot increases the rate of morbidity and mortality in addition to duration of hospital stay and healthcare costs, due to accompanying comorbidities and extremity amputations [7,8]. Previous studies have found amputation rates varying between 5.2 and $39.4 \%$ [9-11]. In the present study, the rate of amputation was higher than those reported in the literature. This is probably because our hospital is the final step healthcare center providing service in our region and, therefore, all complicated cases are being referred to our center.

Diabetic foot is a condition of the elderly, and the mean age of patients in previous studies varied between 57 and 76 years [12-14]. While the effect of age on amputation was found to be significant in a study, another study did not demonstrate such an effect $[15,16]$. In the present study, the mean age was over 60 years, and age was not found to be a factor significantly affecting amputation.

In addition, previous studies did not report a significant effect of sex or DM duration on amputation $[15,16]$. In our study, sex, similarly, did not influence amputation, although DM duration had a significant effect on amputation and was significantly lower, compared to nonamputated group. This can be explained by poor glucose regulation in patients with a diabetes duration of less than five years, as the mean HBA1c level was higher among patients with diabetes for less than five years in this study.

In the study of Namgoong et al. [16], renal, gastrointestinal, and pulmonary disease had a significant effect on amputation in patients with DFU, while no significant effect was found for comorbidities such as cardiac, hepatobiliary, opthalmologic, musculoskeletal system, nervous system, genitourinary, metabolic and malignant diseases, or hypertension. Hypertension and peripheral artery disease were shown to have significant effects on amputations in another study [17]. In the study of Beaney et al. [18], hypertension was found to have a significant effect on amputation, while peripheral artery disease was not considered comorbidity affecting amputation. In the present study, coronary artery disease was the only comorbidity with a significant impact on amputation.

In the study of Demirci et al. [13], 23 of 52 patients had osteomyelitis. Pemayun et al. [19] also reported that 27 of 47 amputated cases had osteomyelitis. However, the relation between osteomyelitis and amputation was not significant. On the other hand, in the study of Wukich et al. [20], 155 of 229 patients had osteomyelitis, 94 of those underwent amputation, and the relation between amputation and osteomyelitis was found significant. In the present study, osteomyelitis was found to be a factor affecting amputation. The patients who underwent amputation were at advanced stage and $87.5 \%$ had osteomyelitis. In terms of the effects of laboratory findings on amputation, Beaney et al. [18] reported that HbA1c levels higher than $7.5 \%$ had an impact on amputation. In the study of Pemayun et al. [19], HbA1c $\geq 8 \%$ and triglycerides $\geq 150 \mathrm{mg} / \mathrm{dL}$ were also found to have significant effects on amputation. Decreased $\mathrm{Hb}$ and elevated CRP were reported to have significant effects on amputation in another study [17]. In a study performed by Namgoong et al. [16] in patients with DFU, WBC, CRP, ESR, Hb, and albumin levels were found to be the factors significantly affecting amputation, while HbA1c had no such effect. A previous meta-analysis also demonstrated that HbA1c was a significant factor affecting lower extremity amputations in diabetic patients [21]. The effects of laboratory findings on amputation, as demonstrated in the present study, are consistent with the literature findings. Moreover, neutrophil count and elevated neutrophil/lymphocyte ratio also had a significant impact on amputation. 
Furthermore, several classification systems are used to predict diabetic foot amputations [22]. According to Pemayun et al. [19], the WagnerMeggitt Classification of Grade 4 had a significant impact on amputation. Jeon et al. [17] used five different classification systems for DFU and found all to be effective in predicting amputation. The results of their multivariable analysis revealed that the Wagner-Meggitt Classifications of Grade 3 and 4 , and University of Texas Classifications of Stage C, D, and Grade 3 had a significant relationship with amputation. In the aforementioned study, the majority of the DFU were located at the toes. In the present study, localization of DFU and the effects of the Wagner-Meggitt and University of Texas Classifications on amputation were found to be similar.

The limitation of this study is the low number of patients and it is a retrospective study.

Conclusion: The presence of coronary artery disease, duration of hospital stay, presence of osteomyelitis, decreased levels of albumin and $\mathrm{Hb}, \mathrm{WBC}$, neutrophil, neutrophil/lymphocyte ratio, $\mathrm{HbA1c}$ and elevated ESR are crucial for predicting amputation in patients referring to emergency units with DFU. The WagnerMeggitt Classification of Grade 4 and University of Texas Classification of Stage D and Grade 3 are also significant to predict amputation.

Declaration of Conflicting Interests: The authors declare that they have no conflict of interest.

Financial Disclosure: No financial support was received.

\section{REFERENCES}

1. Hingorani A, LaMuraglia GM, Henke $P$, et al. The management of diabetic foot: A clinical practice guideline by the Society for Vascular Surgery in collaboration with the American Podiatric Medical Association and the Society for Vascular Medicine. J Vasc Surg. 2016; 63:3-21.
2. Janet LK, Irl BH. Medical management of patients with Diabetes during perioperative period. In: Bowker $\mathrm{JH}$, Pfeifer MA, eds, Levin and O'Neal's The Diabetic Foot. 7th edition. Philadelphia: Mosby. 2008; 387-401.

3. David GA, Lavery LA, Harkless LB. Treatment based classification system for assessment and care of diabetic feet. J Am Pod Med Assoc. 1996; 86:311-6.

4. Boulton AJ, Armstrong DG, Albert SF, et al. Comprehensive foot examination and risk assessment: a report of the task force of the foot care interest group of the American Diabetes Association, with endorsement by the American Association of Clinical Endocrinologists. Diabetes Care 2008; 31:1679.

5. Armstrong DG, Lipsky BA. Diabetic foot infections: stepwise medical and surgical management. Int Wound J 2004; 1:123-32.

6. Jain AKC. A new classification of diabetic foot complicatıons: a simple and effectıve teaching tool. The Journal of Diabetic Foot Complications. 2012; 4:1-5.

7. Robbins JM, Strauss G, Aron D, et al. Mortality Rates and Diabetic Foot Ulcers. J Am Podiatr Med Assoc 2008; 98:489-93.

8. Cavanagh P, Attinger C, Abbas Z, et al. Diabetes Metab Res Rev 2012; 28:107-111.

9. Yesil S, Akinci B, Yener S, et al. Predictors of amputation in diabetics with foot ulcer: single center experience in a large Turkish cohort. Hormones (Athens) 2009; 8:286-95.

10. Pscherer S, Dippel FW, Lauterbach S, Kostev K. Amputation rate and risk factors in type 2 patients with diabetic foot syndrome under real-life conditions in Germany. Prim Care Diabetes 2012; 6:241-6.

11. Ashraf MN, Khalil-ur-Rehman, Malik KI, Iqbal GS. Epidemiology and outcome in patients of diabetic foot. J Ayub Med Coll Abbottabad 2011; 23:122-4.

12. Skrepnek GH, Mills JL Sr, Armstrong DG. A Diabetic Emergency One Million Feet Long: Disparities and Burdens of Illness among Diabetic Foot Ulcer Cases within Emergency Departments in the United States, 2006-2010. PLoS ONE 2015; 10:1-15.

13. Demirci H, Aktürk M, Karakoç A, et al. Diyabetik ayak ülserli hastalarda mikrovasküler komplikasyonların sıklığı ve osteomiyelit ile ilişkisi. Gazi Medical Journal 2006; 17:209-12.

14. Setacci C, Sirignano P, Mazzitelli G, et al. Diabetic Foot: Surgical Approach in Emergency. Int J Vasc Med. 2013; 2013:296169. 
15. Durgun O, Durgun AG, Ersoy CÖ, ve ark. Diyabetik Ayak Gelişmiş Olgularda Amputasyon Gerekliliğini Belirleyen Faktörlerin Retrospektif Olarak İncelenmesi. Uludağ Üniversitesi Tıp Fakültesi Dergisi 2012; 38:5962.

16. Namgoong S, Jung S, Han SK, Jeong SH, Dhong ES, Kim WK. Risk factors for major amputation in hospitalised diabetic foot patients. Int Wound J 2016; 13:13-19.

17. Jeon B-J, Choi HJ, Kang JS, et al. Comparison of five systems of classification of diabetic foot ulcers and predictive factors for amputation. Int Wound J 2016; doi: 10.1111/iwj.12642.

18. Beaney AJ, Nunney I, Gooday C, Dhatariya K. Factors determining the risk of diabetes foot amputations--A retrospective analysis of a tertiary diabetes foot care service. Diabetes Res Clin Pract. 2016; 114:69-74.
19. Pemayun TG, Naibaho RM, Novitasari D, et al. Risk factors for lower extremity amputation in patients with diabetic foot ulcers: a hospital-based case-control study. Diabet Foot Ankle. 2015; 6:29629.

20. Wukich DK, Hobizal KB, Sambenedetto TL, et al. Outcomes of Osteomyelitis in Patients Hospitalized With Diabetic Foot Infections. Foot Ankle Int. 2016; Aug 22. pii: 1071100716664364.

21. Zhou ZY, Liu YK, Chen HL, et al. HbA1c and Lower Extremity Amputation Risk in Patients With Diabetes: A Meta-Analysis. Int J Low Extrem Wounds. 2015; 14:168-77.

22. Monteiro-Soares M, Martins-Mendes D, Vaz-Carneiro A, et al. Classification systems for lower extremity amputation prediction in subjects with active diabetic foot ulcer: a systematic review and meta-analysis. Diabetes Metab Res Rev 2014; 30:610-22. 
Dicle Tıp Dergisi / Dicle Medical Journal

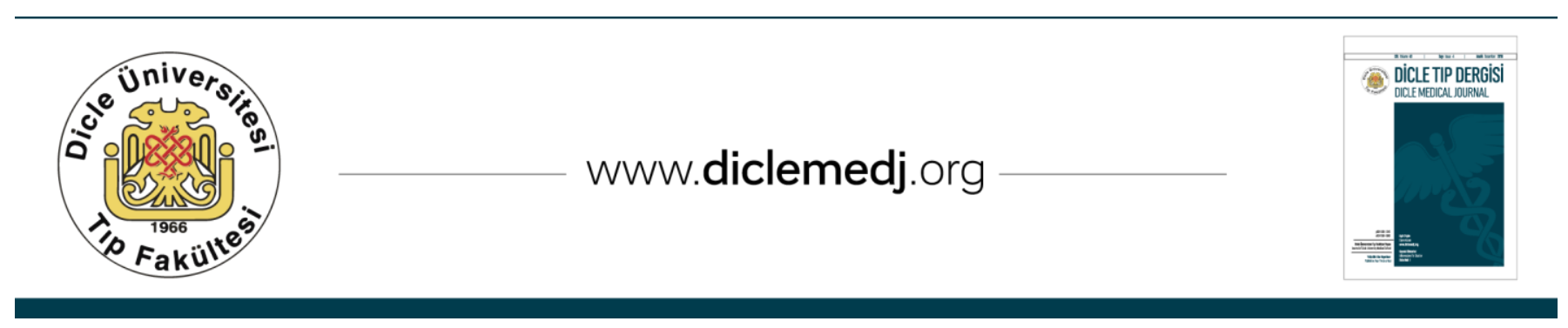

